\title{
Primary Mediastinal Yolk Sac Tumor in a 66-Year-Old Woman
}

\author{
Ugur Coskuna Nazan Günel $^{a}$ Yesım Yıldırım ${ }^{b}$ Leyla Memisc \\ Z. Melda Boyacıogluc
}

Departments of a Medical Oncology, bInternal Medicine and CPathology, Gazi University Medical School, Ankara, Turkey

\section{Key Words}

Yolk sac tumor, mediastinal · Elderly female

\begin{abstract}
Objective: To report a rare case of nonseminomatous extragonadal germ cell tumor in a 66-year-old female with primary yolk sac tumor of the mediastinum. Clinical Presentation and Intervention: A 66-year-old female was admitted to our hospital with a history of chest pain for 1 month. Computerized tomography of the thorax showed a left paracardiac mass adjacent to the aortic arch, left main pulmonary artery and pericardium. Total surgical excision could not be performed, but several biopsies which were taken through a thoracotomy revealed yolk sac tumor of the mediastinum. Systemic chemotherapy was started, but no response was observed and the patient died after one course of chemotherapy. Conclusion: Nonteratomatous mediastinal germ cell tumors are virtually nonexistent in women. To our knowledge, this is the oldest female patient with a primary mediastinal germ cell tumor. Chemotherapy was not effective especially in an old patient. We suggest surgery should be considered as primary treatment modality if diagnosis is made at an early stage.
\end{abstract}

Copyright $\odot 2002$ S. Karger AG, Basel

\section{Introduction}

Germ cell tumors are relatively infrequent neoplasms that usually originate in gonads. They have also been described in other sites, including pineal gland, retroperitoneum, mediastinum and sacrococcygeal area. It has been estimated that gonadal germ cell tumors may account for approximately $1-15 \%$ of mediastinal tumors in adults and approximately $25 \%$ in children $[1,2]$. Most germ cell tumors of the mediastinum are teratomas followed by seminomas [3-5]. Yolk sac tumors are the least common germ cell tumors in the mediastinum and appear to have a special predilection for males. The reasons for this male occurrence remain unknown. Although extragonadal yolk sac tumors have occurred in the head in female children and women [6], tumors arising in the mediastinum are exceedingly rare. In this report, we present the clinical, radiographic, and pathological findings in the oldest female patient, to our knowledge, with primary mediastinal yolk sac tumor.

\section{Case Report}

A 66-year-old female was admitted to our hospital with a history of chest pain for 1 month. A chest X-ray revealed a left paracardiac mass (fig. 1a). Physical examination of the patient was normal. A computerized tomographic (CT) can showed a solid mass $(6.5 \times 12$ $\times 9 \mathrm{~cm}$ in diameter) adjacent to the aortic arch extending to the left

\begin{tabular}{ll}
\hline KARGER & ○ 2002 S. Karger AG, Basel \\
Fax +4161306 12 34 & 1011-7571/02/0114-0218\$18.50/0 \\
$\begin{array}{l}\text { E-Mail karger@karger.ch } \\
\text { www.karger.com }\end{array}$ & Accessible online at: \\
www.karger.com/mpp
\end{tabular}

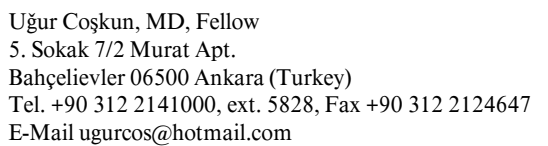

Tel. +90 312 2141000, ext. 5828, Fax +90 3122124647

E-Mail ugurcos@hotmail.com 

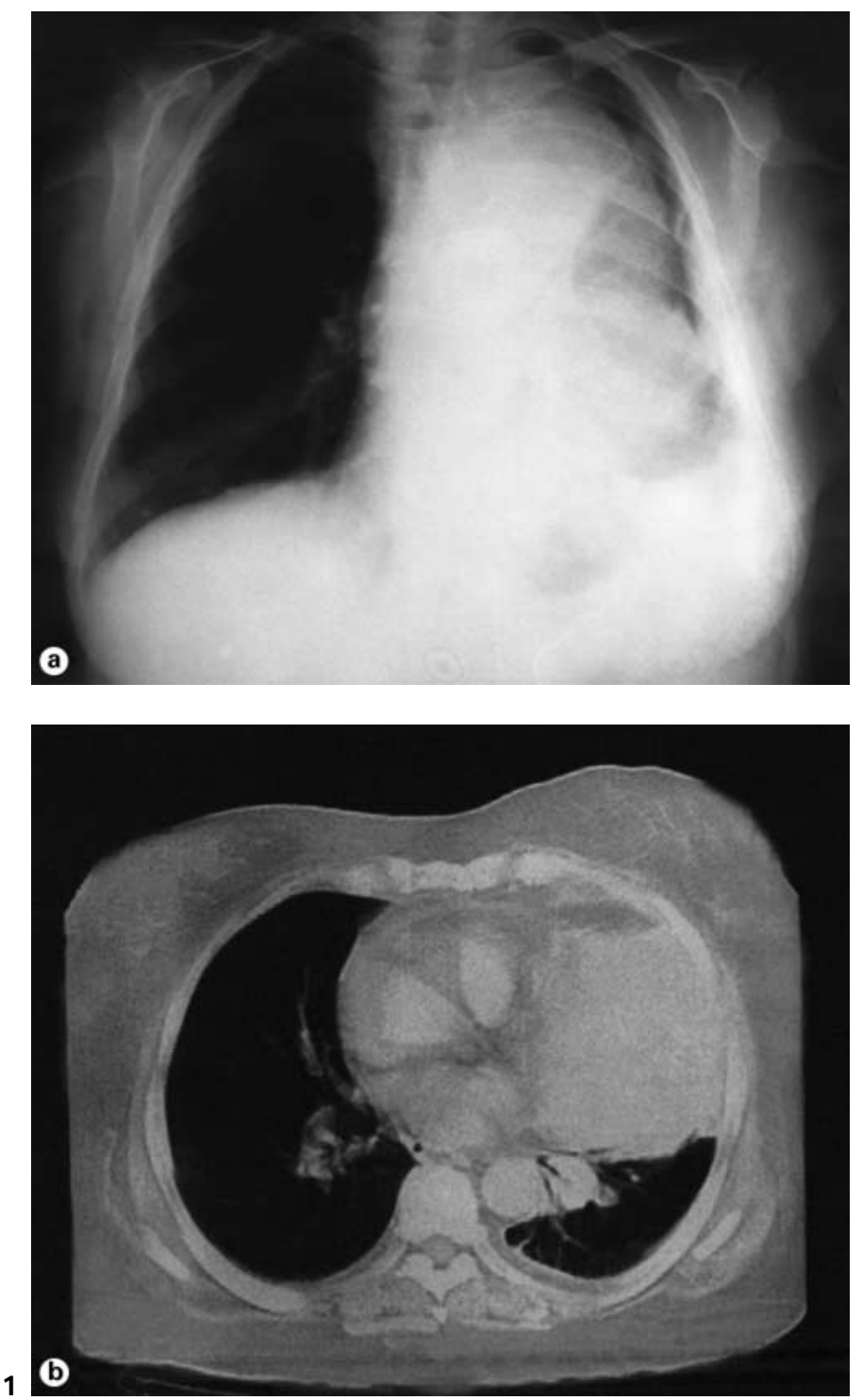

Fig. 1. a Chest X-ray showing leftparacardiac mass. b CT scan showing left paracardiac mass.

Fig. 2. a Yolk sac tumor showing papillary and glandular alveolar pattern. HE. $\times 100$. b Yolk sac tumor; a typical perivascular formation called Schiller-Duval body. HE. $\times 200$. c Yolk sac tumor showing loose myxomatous pattern containing numerous cavities and channels. HE. $\times 100$.
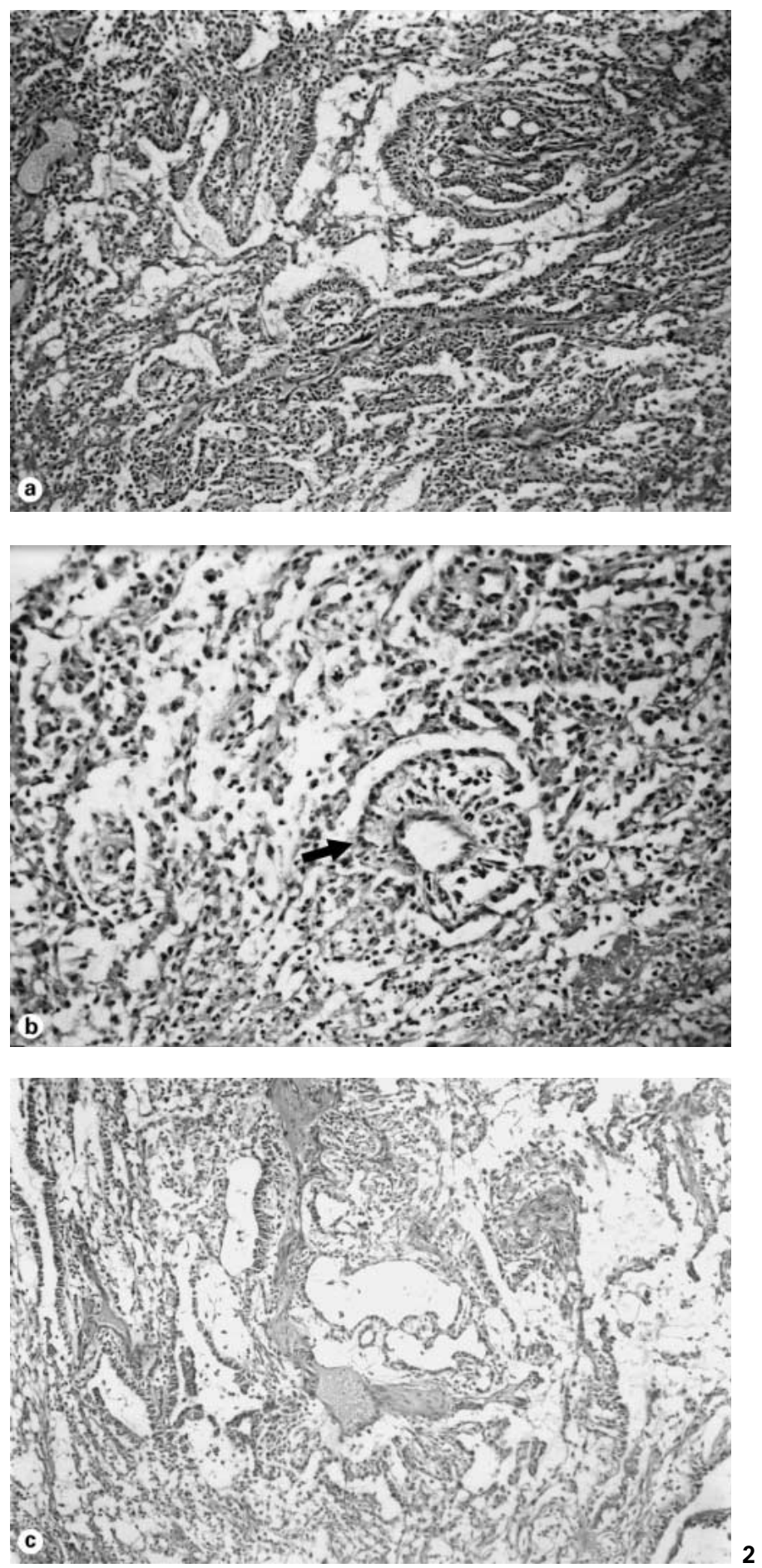

An exploratory thoracotomy revealed that a fragile mediastinal mass extended from the posterior to anterior mediastinum. The mass was adherent to great vessels and it displaced the mediastinal structures anteriorly. Due to invasion of the great vessels, complete resection of the tumor was not attempted. Instead, six biopsies were taken 
of the lesion, ranging up to $2 \mathrm{~cm}$ in diameter. On gross examination, the specimens were tan and friable. The cut surface of the tumor disclosed both solid parts with necrotic and hemorrhagic areas and cystic space filled with mucoid material. Microscopically multiple sections of tumor revealed papillary, glandular and alveolar patterns (fig. 2a) as well as typical perivascular formations (Schiller-Duval bodies, fig. $2 b$ ). In addition, there was a microcystic pattern characterized by a loose meshwork of small cysts (fig. 2c). Other germ cell elements were not identified. Immunohistochemical studies showed that tumor cells were focally positive for $\alpha$-fetoprotein. Stains for carcinoembryonic antigen, keratin, S-100, and placental alkaline phosphatase were uniformly negative.

Owing to the presence of residual tumor, the patient was placed on a two-drug combination chemotherapy regimen with cisplatin and etoposide. After one course of chemotherapy, she deteriorated. A follow-up CT scan showed progression of the tumor and she died 2 months after the initial diagnosis.

\section{Discussion}

Yolk sac tumors occur most frequently in the ovaries and testes. While involvement of extragonadal sites is rare [7-9], the anterior mediastinum is the most frequent site for this neoplasm, which has been reported in children, older adolescents and adults [1,7-10].

A recent study of 322 patients with germ cell tumors of the mediastinum [1] showed that 64 patients with nonseminomatous and nonteratomatous lesions including yolk sac tumor were all males between 14 and 63 years of age (mean 30 years). Thirty-eight cases of primary mediastinal yolk sac tumor were reported in another study and none occurred in females [11]. The first female patient, who was reported in 1985 , remains the youngest patient with this tumor. A review of the literature shows that all of the previously reported cases of mediastinal yolk sac tumors in females were in the pediatric age-group $[10,12]$. Our case is thus the oldest female patient with a primary mediastinal yolk sac tumor.

Yolk sac tumors are aggressive neoplasms with early hematogenous metastases. The clinical presentation in most patients is remarkably uniform. Due to rapid growth, the tumors can become quite large before they can be detected. Because the tumor adheres to vascular structures, complete resection is often difficult, as our case illustrates. The disease tends to recur rapidly in spite of initial response to chemotherapy. Patients usually die from pulmonary complications. In this case, the tumor showed very aggressive behavior and did not respond to chemotherapy, as the patient died within 2 months of presentation. Although this patient died, the combination of current multiagent chemotherapy and aggressive surgical approach may result in improvement in some patients with this uncommon neoplasm [13].

\section{Conclusion}

Nonteratomatous mediastinal germ cell tumors are virtually nonexistent in women. To our knowledge, this is the oldest female patient with a primary mediastinal germ cell tumor.

\section{References}

1 Moran CA: Germ cell tumors of the mediastinum. Pathol Res Pract 1999;195:583-587.

2 Knapp RH, Hurt RD, Payne WS, Farrow GM, Lewis BD, Hahn RG, Muhm JR, Earle JD: Malignant germ cell tumors of the mediastinum. J Thorac Cardiovasc Surg 1985;89:8289.

3 Berghn NP, Gatzinnsky P, Larsson S, Lundin $\mathrm{P}$, Riedell B: Tumors of the thymus and thymic region. III. Clinicopathological studies on teratomas and tumors of germ cell type. Ann Thorac Surg 1978;25:107-111.

4 El-Domeiri AA, Hutter RV, Pool JL, Foote FW Jr: Primary seminoma of the anterior mediastinum. Ann Thorac Surg 1968;6:513-521.

5 Lack EE, Weinstein HJ, Welch KJ: Mediastinal germ cell tumors in childhood: A clinical and pathological study of 21 cases. $\mathbf{J}$ Thorac Cardiovasc Surg 1985;89:826-835.
6 Gangopadhyay K, McArthur PD, Martin JM, Saleem M: Endodermal sinus tumor of the maxillary sinus: A case report. Ear Nose Throat J 1999;78:376-378.

7 Gooneratne S, Pancita K, Shanta S, Talerman A: Anterior mediastinal endodermal sinus (yolk sac) tumor in a female infant. Cancer 1985;56:1430-1433.

8 Burt ME, Javadpour N: Germ cell tumors in the patient with apparently normal testis. Cancer 1981;47:1911-1915.

9 Chamsi-Pasha M, Bernstein A: Mediastinal yolk sac tumor mimicking pericardial effusion. Thorax 1988;43:339-340.

10 Billmire D, Vinocur C, Rescorla F, Colomboni P, Cushing B, Hawkins E, London WB, Giller R, Lauer S: Malignant mediastinal germ cell tumors: An intergroup study. J Pediatr Surg 2001;36:18-24.
11 Moran CA, Suster S: Primary germ cell tumors of the mediastinum. I. Analysis of 322 cases with special emphasis on teratomatous lesions and a proposal for histopathological classification and clinical staging. Cancer 1997;80:681690.

12 Brown K, Batra P: Mediastinal germ cell tumor in a young woman. Med Pediatr Oncol 1989; 17:164-167.

13 Moran CA, Suster S, Koss MN: Primary germ cell tumors of the mediastinum. III. Yolk sac tumor, embryonal carcinoma nonteratomatous germ cell tumors of the mediastinum - a clinicopathologic, choriocarcinoma, and combined and immunohistochemical study of 64 cases. Cancer 1997;15:699-707. 